\title{
National Integration in Humanities and Development: The Way Forward
}

\author{
Salihu Bakari \\ http://dx.doi./org/10.4314/ujah.v18i2.21
}

\begin{abstract}
This paper examines the following concepts nation and its attributes; national integration, development and social studies education. The paper also discusses the concept of national integration, theories of nation al integration and the problems of national integration in Nigeria. It further discusses the factors of disunity and under development, other nations have used social studies education in integrating their citizens for national development and prowess. The paper demonstrates how social studies education can be used in integrating the Nigerian citizens for national development. The paper concludes with recommendations.
\end{abstract}

\section{Introduction}

Education is a powerful phenomenon that influences man from day one to the last day. It stresses knowledge, understanding and general development of an individual and the nation as opposed to propaganda which overriding interest and focus is persuasion. Social studies education as an academic discipline touches so closely on all aspects of public and individual life that there are both implicit and explicit demands for it worldwide. Its main thrust is on socializing and humanizing the individual in the society in order to help him contribute meaningfully to its growth and development. 
National integration and development is multidimensional in nature as it is characterized with social, political, economic, religious, scientific and technological perspectives which an interdisciplinary subject like social studies is well fitted for its handling. Social studies education has great potentialities for integrating the diverse nationalities in Nigeria if properly implemented in all the levels of education in the country namely nursery, primary; junior secondary school, senior secondary schools and tertiary with the right caliber of teachers.

\section{The Concept of National Integration}

The difficulty of attempting a precise definition of the concept of "integration" has led to the adoption of three basic approaches: structural, cultural and Marxian, though none of the approaches is mutually exclusive. Here, integration is viewed in terms of the extent to which part interact and complement each other in other to constitute viable whole. It is within this framework that national integration sis considered as involving a process of holding tightly together the various nationalist or ethnic groups and institution in a dovetailed manner through the bonds of contrived structures, norms and values.

National integration is also conceived interims of degrees. Under this framework, generally, there could be vertical integration, for instance, of social classes in the society in question, as well as horizontal integration, e.g. the integration of ethnic groups. The operation definition of national integration is the harmonious coexistence of diverse social groups (Bello 1987).

Problems of national integration are viewed in a special way. The problems of national integration in Nigeria are:

a. ethnicity 
b. hang-over of early empires, state and kingdoms in the Nigeria area;

c. unhealthy formation and development of political parties in Nigeria; and

d. unabated passion for states-creation in Nigeria.

\section{The Conceptual Framework}

The following concepts are being defined to serve as operational definitions to give a proper grasp of the issues in the topic under discussion. Ezegbe 1994 defines a nation as people living in the same place and sharing the same values, resources, and psychic energy for the common good of its members and for their general development. According to Kazi (2002) every nation has the following attributes or features.

i. Objective Features: Which include the geographical entity, the people or citizens and independent national expressive symbols.

ii. Subjective Features: Such as historical memory, mutual affection, consciousness of distinctiveness and common destiny.

National Integration is the unity of the various ethnic groups in the country or nation in such a way that they see one another as brothers and sisters devoid of tribal sentiments, nepotism and all other vices that bring polarization of the people (Usara 2001). This means the coming together of Nigerian citizens, to speak with one voice, appreciate the circumstances of their nationality, contribute meaningfully to the development of their country and jointly protect the sovereignty of their country. It is a sort of action that 
means a collective responsibility to swim and sink together in a genuine spirit of brotherhood and sisterhood.

National Development is the possession of adequate human and natural resources, the availability of capital, industrial, expertise, technological, know-how and an educated labour force for better living standards. Social Studies Education is a value-laden and value-free subject in the Nigerian school system which studies man's behaviours and activities in an integrated fashion (Kazi 2002).

\section{Factors of Disunity and Underdevelopment in Nigeria}

Ogunsaya (1990) Onu (1992) Ezema (2002) Bello (2003) identify religious bigotry, bribery and corruption, poverty, lack of legitimacy, unhealthy cleavages; wrong conception of political parties; lopsided development, marginalization; ethnic religious conflicts; low level of political sophistication; distrust of leadership and poor followership are factors of underdevelopment. Stretching the list of vices in Nigeria where these scholars stop are drug peddling; smuggling; political dishonesty and thuggery; winner takes all syndrome; certificate rocketry; advanced sea fraud called "419", hired assassins; bomb explosions; students rampage; workers strikes; examination malpractices; cultism and threats of disintegration to name among others. All the above are manifestations or indicators that all is not well with Nigeria as a nation. It implies that there is the total absence of civil values or values-dispositions as democracy, responsibility, acceptance, cooperation, tolerance, loyalty, discipline, rationality, consideration, independence, freedom, diligence and integration to name but a few which a subject like social studies can play a positive role to promote in the citizens. Let take a few of these 
factors of disunity and Underdevelopment in Nigeria and discuss them briefly. Thus:-

a. Lack of Legitimacy: Most governments in Nigeria lack legitimacy for confidence building and proper exertion of authority. This legitimacy according to Onu (1992) has to do with the belief that government institutions and authorities are morally valid and widely accepted. In this direction, decisions and directives of leaders are more likely to be accepted and obeyed by the followers. But what we have in Nigeria are imposed or selected leaders with false and fake followers.

b. Unhealthy Cleavages: These are demonstrated in the names of religion, geographical setting, political inclination, ethnicity to name among others which result in individual idiosyncrasies that will bring about violent and destructive activities.

c. Conception of Political Parties: This is seen as reflections of primordial interests of the three (3) major ethnic groups of Hausa, Igbo and Yoruba. To Ogunsaya (1990) this has a historical and constitutional origin. Thus during the $1 \mathrm{st}$ Republic we had:

i. Northern Peoples Congress (NPC) for the Hausa-Fulanis.

ii. National Council of Nigerian Citizens (NCNC) for the Igbos in the Eastern Region.

iii. Action Group (AG) for the Yorubas in the Western Religion.

During the 2nd Republic it was the same pattern thus:

i. National Party of Nigeria (NPN) - North,

ii. People Redemption Party (PRP) -North,

iii. Great Nigerian Peoples Party (GNPP) - North,

iv. Nigerian People Party (NPP) - East, 
v. Unity Party of Nigeria (UPN) - West.

Likewise in the 3rd Republic the parties were:

i. National Republic Convention (NRC) - North,

ii. Social Democratic party (SDP) - South.

In the 1990s the two dominant parties were;

i. All Nigeria People's Party with Northern Muslims Coloration,

ii. People's Democratic Party - the ruling party with southern Christians coloration.

As a matter of fact Onu (1992) found out that Nigerian Students voted along the same line with their parents and specifically they voted for the presidential candidate from their own ethnic group.

d. Low Level of Political Sophistication: To Kazi (2002) most Nigerian politicians fail to accept and recognize the fact that democracy strives and lives on the concepts of majority rule and minority views; substitution of bullets with ballots, substitution of breaking of heads with counting of heads and scratch my back I scratch your back e.t.c. That in democracy we need a firm, dedicated and fair minded leadership and not a self centred, privilege and narrow ethnic or religious interest leadership who engages in political thuggery, assassination of opponents with opposing views, overt victimization and intimidation.

e. Distrust on Leadership: A widespread resentment and distrust of leaders by the followers is a pointer to a serious problem of national integration and development. The element of distrust in Nigeria permeates geo-ethnic relations 
which militate against the principles of representative federalism.

f. Indiscipline: With manifestations such as cheating in examination, secret cult, political instability, certificate racketry, advanced sea fraud or 419 human trafficking, hired assassins, arsons, bomb-explosions, prostitution to name among others.

g. Bribery and Corruption: Ezema (2002) sees Nigeria as the most corrupt nation on the face of the earth. In the same vein the United Nations Development Programme (UNDP) quoted by Bello (2003) ranked Nigeria as 26th poorest country in the world with 70 out of every 120 Nigerians living in penury!

The present government of Obasanjo has created some organizations such as National Poverty Eradication Programme (NAPEP) National Economy Empowerment and Development Strategies (NEEDs) Independent, Corruption and other related Offences Commission (ICPC) and Economic and Financial Crimes Commission (EFFC) to name but a few to tackle the problem head long but we are waiting for the result.

These and other social problems not discussed here hinder national integration and development in Nigeria. There is therefore the urgent need to come out with a curricular artifact like social studies to rescue the situation. This is because other nations of the world like Germany and USA have used it to attain national cohesion and impressive development.

How other Nations used Social Studies Education for National Integration, Development and Prowess:

a. United States of America: Social Studies Education in America essentially aims at leading boys and girls to find 
excitement and motivation in exploration, inquiry and discovery with emphasis in developing competences, attitudes and values of citizens in a fee society. The USA uses social studies education to teach community life, love for ones country, defending the territorial integrity of one's country; conservation and rational use of resources; increased productivity and respect for the rights of other citizens. In short primary pupils and students are prepared for national development and prowess. The teaching of social studies in America according to Kissock (1981) is focused on moral and values education which enable pupils and students to make rational decisions based on values-clarifications for democratic living.

b. German Democratic Republic (GDR): The thrust of the goals of social studies education in GDR as declared by Shafer (1981:85) is: Students should distinguish themselves for their attitudes towards socially useful labour for their political, cultural and personal characteristics for their willingness to help shape the life of the society. In addition social studies is to provide a readiness to defend GDR and the socialist committee of nations.

Definitely the above served as a sort of ideology for GDR to imbibe civic responsibilities in the citizens which help to sharpen their thinking abilities to make gains in both social and economic competencies to achieve self-reliance.

From the above two examples it would be seen that social studies education has tremendous role to play in integrating the citizens of the nation for national development. It is the most effective curricular artifact or instrument for mobilization of citizens to 
realize the national objectives of any country. This can be seen from its global goals as enunciated by Jarolimek (1977) such as

a. The inculcation of attitudes and values;

b. The acquisition of skills;

c. The acquisition of knowledge and understanding.

Realizing the importance of social studies objectives Udo (1974) Dubey (1980) Adaralegbe (1983) Adeyoyin (1987) Joof (1989) and Kazi (1999) and Okam (1991 and 1992) advocate that emphasis in the subject should be on:

a. Self-realization through experiences that foster individual's growth in knowledge, skills and personal values;

b. Human relationships through multicultural education and development of interpersonal skills and analysis of intergroup problems;

c. Civic responsibilities which are developed in the pupils or students.

d. Sharpening of thinking ability in decision making activities;

e. Right attitudes to work;

f. Respect for the rule of law;

g. Respect for the constituted authority; and

h. Development of a sense of cooperation, tolerance, sympathy and fair play.

How to use Social Studies Education in Integrating the Nigerian Citizens for National Development

The primary aims of introducing social studies education in Nigeria was to heal the wounds of the 1967 - 1970 civil war; to promote unity in diversity; teach the national symbols; and promote the spirit of interdependency among the various ethnic groups (Udoh 1974). By this social studies education is expected to 
inculcate the concepts of nationalism, unity and interdependency of the 300 different ethnic nationalities in the learners in schools and colleges.

To do this effectively our social studies teachers at whatever level of education in Nigeria (Nursery, Primary, Secondary or Tertiary) must be conversant and knowledgeable with our national objectives and our social studies objectives. "According to our national policy on education (FRN $1981 \&$ 1998) the National Objectives include: the development of:-

i. Free and democratic society;

ii. United, strong and self reliant nation;

iii. Just and egalitarian society;

iv. Great and dynamic economy;

v. Land of bright and full opportunities for all citizens;

These objectives call for the development of social skills, groups skills, social values, desirable attitudes and behaviours by social studies teachers in the learners for national integration and development.

Specifically social studies teachers can use the following techniques and approaches to promote spirit for national integration and development among the pupils and students.

1. Whole class discussion: to popularize Nigerian national expressive symbols e.g. The flag, anthem, coat of arms, pledge, constitution and currencies with feelings of patriotism, loyalty and conformity which are ingredients of national consciousness and panacea for national integration and development.

2. Through Games and Simulation Games: Social studies teachers can teach or promote positive values and attitudes 
like cooperation, tolerance, respect for authority and commitment to group activities and goals.

\section{Using Multicultural Education Approach: National} consciousness and unity or integration in learners can be achieved. This is because multicultural education is centred on ethnic composition of the country, contribution of each ethnic group to the so called "national cake", the sense of strength in diversity of the various ethnic groups; the development of polity culture like modes of dressing, hairdo, songs, dance, foods, encouragement of inter-ethnic marriage among the citizens, social classes in the society (upper, middle and lower) with their attendant characteristics.

4. Through Group Discussions: Social studies teachers can sensitize pupils or students in the economy interdependency among states in Nigeria which enhance healthy rivalry and specialization for higher productivity for national development for example Cocoa in Ondo State, Beniseed Benue, Palm Oil -[mo; Cattle - Adamawa, Petroleum Rivers; Iron and Steel — Kogi; Rubber — Edo; Groundnut Kano and Dairy Products - Plateau.

5. Using Panel Discussion: Social studies teachers can x-ray the roles of the Nigerian constitution. Here panelists with the teacher as the moderator explain the various components and functions of the different arms of government (Executive, Legislative, Judiciary) and the functions of the different tiers of government (Local State and Federal) the fundamental rights and responsibilities of the citizens e.t.c.

6. Through Debates: Social studies teachers can use rights Vs responsibilities to imbibe in the learners democratic values like freedom of opinion, liberty, justice, tolerance, obedience, 
sanctions to name among others which can enhance political socialization for national integration and development.

7. Using Concepts and Generalizations Strategy: Which can promote an ideology like self-reliance, self-actualization or welfarism in the learners which should serve as a tonic of a kind to energize them for an action to change the economic, social cultural, political and intellectual structures of the Nigerian society for meaningful growth and development. Using the concept "Self-reliance" which connotes the right freedom, capacity and willingness of the citizens to define and articulate their own goals or mission as a community or nation through their own efforts or self-instituted programme for their own integration and development. In this regard Ukeje (1991:5) asserts: Self-reliance implies revolutionary transformation or revolutionary modernization or indeed technological revolution whereby we produce what we use and use what we produce or we produce what we eat and eat what we produce.

8. Use of Ideology: Nigeria needs an ideology of a kind in social studies education to provide a set of concepts and principles we need to guide, synchronize and mobilize the citizens towards national integration and development. Social studies education through an effective ideology can teach citizens to guard against a situation where the country economic resources are used recklessly and deliberately destroyed by unscrupulous and unpatriotic Nigerians leaving us with the legacies of bitterness, plunder, destruction and disintegration through religious and ethnic conflicts. Our perverted tastes and values which were developed during the oil boom but now oil doom can be corrected and redirected through an ideology nurtured by social studies teachers in our 
schools and colleges. In the same vein the imposed western liberal capitalism in Nigeria in the forms of privatization and commercialization needs serious revisiting as it is paradoxically a collary or collecteral of imperialism and neocolonialism which is the anti-thesis of a true national development we are yearning for.

\section{Theories of National Integration}

It is better to examine some theories on the emergence and development of nation-building and integration in the world. These theories are those of Thorson (1973) Stankiewiz (1976) and Marcidis (1980) all expatiating on theories of John Locke (16321704), Rousseu (1762), Karl Marx (1818 -1883) and Herbert Spencer (1820-1903).

i. The Divine Right of Kings Theory: The theory postulates that monarchs or kings were regarded as having been ordained by God and given the authority to rule others as directed by God. Their wills were laws and they did no wrong. They extorted absolute obedience, loyalty and cooperation from their subjects. The application of their rules was sufficient to integrate or unite all the subjects and areas into one entity.

ii. The individual consent theory: quoting John Locke (16311704) the theory postulate that men and women lived in state of salutary life and nature with certain natural rights for example life, liberty and property which they could not protect individually but needed a common authority to mobilize, direct and safeguards them. This eventually gave rise to the emergence of political authority and powers over some peoples to rule others who have given their consent for collective entry and nation-building. 
iii. The social contract theory: this is an extension of the individual or consensus theory of John Locke (1632 -1704) and Rousseau (1762) which posits that a state or government obtains its authority to rule from an agreement or contract entered into between her and people. By implication every party in the contract must keep to its terms and any breach of the agreement by any part the other party is no longer obliged to keep its own part. The social contract approach helps in mobilizing recruiting and galvanizing the citizens in a nationbuilding.

iv. The Conflict Theory: this was postulate by Karl Marx (1818-1883) as "dialectical materialism". The theory has two parts (a)" conflict between man and nature; and (b) conflict between classes in the society, "the haves" and the have not" or those who own and control means of production called the "bourgeoisie" and those who effect the production of goods and services called the "workers" or "proletariat" in simple terms in our modern days these are the "employers" and the "employee" who are engaged in a conflict relationship in nation building pursuing their inters. Thus the ruling class looks for and controls others in this nation pr country. The others obey and sell their labour as workers the ruling class in nation building.

v. The organic theory: this was annunciated by Herbert Spencer (1820-1903). It is sort of an evolutionary theory based on "change" whereby a society is seen as a natural organism with natural boundaries (part as economic and politics. This means that all the various organs or part of government must work cooperatively for the development of the economy, education, politics and religion in nationbuilding as a living organism. 
vi. The self-reliance theory: this is a theory that postulates and highlights the capacity and potentiality of every community or society of substantially provide the needs for itself. The theory according to Ukeje (1992) induces individuals, communities, institutions, organization, group, government organs and agencies to rise up and contribute their quotation ensure collectivity and productivity for self relies in all spheres of their quota to ensure collectivity and productivity for self-reliance in all spheres of national integration nationbuilding and development.

\section{Recommendations}

1. The Nigeria Society at large like any other societies in the world needs to be sensitized on citizens individual selfactualization and self-fulfillment.

2. To achieve self-actualization the Nigeria citizens themselves must be ready to face new ideas, challenges and experiences and not to fear taking risks nor to persist on past behaviours.

3. We need to educate the Nigeria society about the choice of professions of our children based on their potentialities.

4. Our social institutions should take care of the major needs of our adults so that they do not degenerate in their psychological development but can aspire to self-esteem needs like independence, competence, self-worth and adequacy.

5. Self-actualization be incorporated into the Nigerian school curriculum with immediate effect and not taught in social studies education along which is already "Saturated".

6. The classroom teachers handling this curriculum should be recognized as playing some crucial roles and therefore given sound orientation towards the attainment of the goals of self- 
actualization in all possible areas of human endeavours for example divergent and convergent thinking processes.

7. Teachers handling self-actualization should help students to "fine tune" their abilities or aptitudes they display at early stages. This calls for creative potential work hunt by any of these means

a. Art fairs.

b. Exposition fairs.

c. Talent reviews.

d. Science fairs.

e. Technology fairs e.t.c.

\section{Salihu Bakari \\ Federal College of Education Kano \\ abubakarmambila2@gmail.com}

\section{References}

Adaralegbe, A. (1983) The Nigerian Social Studies Programme (NNSP) Retrospects and Prospects in NERC Social Studies Teaching Issues and Problems. Benin: Ethiopia Press.

Adeyoyin, F.A. (1987) The Social Studies and Overview in N.P. Adeyoyin, E.E. Obilo and U.S. Ahmadu (Ed) Social Studies. A Book on Methodology. Ibadan; Evans Brothers Ltd.

Anselm Uba (1983) Introduction to Counselling Ile-Ife: University of Ife Press Ltd.

Bello, A. (2003) Stakeholders Renew Concern Overrising Unemployment. The Guardians June 24 pg. 33.

Dubey, D.L. (1980) Social Studies Methods for Nigeria Teachers. Ibadan: University Press Ltd. 
Ezegbe, M.O. (1994) Social Studies Education and NationBuilding in G.W. Joof and M.C. Amadi (Ed) Social Studies in Schools. Onitsha: Outrite Pub.

Jarolimek John (1977) Social Studies in Elementary Education.

New York: Macmillan Publishing Coy. Inc.

Kazi Ndampon Peter (1995) The Arts and Social Sciences as Vehicles for Man's Emancipation in a Locale - Paper Presented at a national Conference of Social Studies

Association of Nigeria (SOSAN) F.C.E. Pankshing.

Makinde Olu (1987), Profile of Career Education. Ibadan: Signal Educational Services Ltd.

Maslow A. (1969) Towards a Humanistic Biology in American Psychology No. 4 Pages 224-735. NERC (1983) The Nigeria Primary Social Studies Curriculum Guidelines Lagos - Nigeria.

NPE (1981) Federal Republic of Nigeria Revised National Policy on Education Lagos: Federal Ministry of Information.

NTI (1990) NCE/DLS Course Book on Social Studies Cycle I Unit 9 Self-Actualization: Kaduna N.T.I. Publication Kaduna Nigeria.

Okolie Animba (1989) From School to Where a Career Choice Work Book for Secondary Schools. Ilorin: University of Ilorin Press Ltd Nigeria.

Segun Idowu (1989) Choosing and Managing your Career. Ibadan: University Press Limited Ibadan. 